\title{
ABCA1, from pathology to membrane function
}

\author{
Ana Zarubica • Doriane Trompier • Giovanna Chimini
}

Received: 16 February 2006/Revised: 15 May 2006 / Accepted: 24 May 2006 / Published online: 21 July 2006

(C) Springer-Verlag 2006

\begin{abstract}
The ABCA1 transporter is the prototype of the A class of mammalian adenosine triphosphate binding cassette transporters and one of the largest members of this family. ABCA 1 has been originally identified as an engulfment receptor on macrophages and, more recently, it has been shown to play an essential role in the handling of cellular lipids. Indeed by promoting the effluxes of membrane phospholipids and cholesterol to lipid-poor apoprotein acceptors, ABCA1 controls the formation of high-density lipoproteins and thus the whole process of reverse cholesterol transport. A number of additional phenotypes have been found in the mouse model of invalidation of the ABCA1 gene. In spite of their clinical diversity, they all are extremely sensitive to variations in the physicochemical properties of the cell membrane, which ABCA1 controls as a lipid translocator.
\end{abstract}

Keywords ABC transporter - Lipid translocation . Tangier disease $\cdot$ Membrane vesiculation

\section{Introduction}

Protein-mediated lipid translocation on cellular membrane is one of the crucial biochemical mechanisms orchestrating organism physiology. Nevertheless, the main molecular actors and their role in lipid handling are still elusive.

Adenosine triphosphate binding cassette (ABC) transporters are one of the largest protein families ubiquitously

A. Zarubica $\cdot$ D. Trompier $\cdot$ G. Chimini $(\square)$

Centre d'Immunologie de Marseille Luminy, INSERM, CNRS,

Université de la Méditerranée,

Case 906, Parc Scientifique de Luminy,

13288 Marseille, Cedex 09, France

e-mail: chimini@ciml.univ-mrs.fr conserved from bacteria to man [36]. In spite of their diversity in terms of substrate handling, they all share a similar "modus operandi", in that the hydrolysis of adenosine triphosphate provides the energy required for active transport of substrates across biological membranes. A significant number of $\mathrm{ABC}$ transporters are involved in the handling of cellular lipids [110]. The fact that the mutations in their genes are associated with pathological phenotypes or even clinically overt diseases related to lipid metabolism emphasises their crucial role in the homeostasis of cellular lipids. ABCA1 is a key playmaker as it controls, at the cell membrane, the initial steps leading to highdensity lipoprotein (HDL) formation and, as a consequence, the whole process of reverse cholesterol transport from peripheral tissues to the liver [57, 109]. In this study, our aim is to review the functional impact of the ABCA1 transporter, highlighting the tight relation between the biochemical activity and the function. ABCA1 acts as a lipid translocator and, as such, modulates the lipid architecture at the membrane and its physicochemical properties. Lipid architecture indeed controls proper membrane functioning both as a physical barrier and as a signalling device. Understanding how it is orchestrated is thus a challenging but essential task.

\section{Structural hints}

The annotation of genomic databases led to the identification of 49 human $\mathrm{ABC}$ proteins classified into seven distinct subfamilies, $\mathrm{ABC}-\mathrm{A}$ through $\mathrm{ABC}-\mathrm{G}$ on the basis of similarity in gene structure, sequence or phylogenesis [36, 98]. In 1994, the identification of ABCA1 and its structural peculiarities led to the definition of a new subclass further named A [63]. The complete genomic 
sequence of the human and mouse ABCA1 genes, including their promoters and regulatory elements, has been determined in the late 1990s [51, 81, 89]. In terms of molecular architecture, ABCA1 is a full-sized $\mathrm{ABC}$ transporter, in that it shows a symmetrical structure with a transmembrane spanning domain (TMD) consisting of six transmembrane segments (TMS) and a nucleotide-binding domain (NBD), repeated in tandem. In the NBDs, all the diagnostic motifs can be found. ABCA1 possesses two extremely large extracellular loops, located between TMS1 and 2 and between TMS7 and 8 (Fig. 1). This is the most original feature of the $\mathrm{A}$ class of the $\mathrm{ABC}$ transporters shared by all the members [33]. Detailed topological studies have been performed in the case of ABCR (ABCA4) and ABCA1 and demonstrated a clear conservation of the topological arrangement [12]. This also holds true for ABCA7 and for the other members on the basis of sequence alignment and hydrophobicity plot comparisons $[9,44]$. These extracellular loops show sequence hypervariability among the ABCA members and may thus participate directly to the functional specification of individual transporters in their appropriate expression compartment.

A precise description of the molecular function of ABCA1 as a membrane translocator is so far not achieved and most of the knowledge on the substrates that it may handle is actually rather indirect. The bottom line experiment would consist in the purification of the transporter and its functional reconstitution in artificial systems such as proteoliposomes. However, considering that ABCA1 is a polytopic membrane protein of very large size, "en masse" production and purification for reconstitution or crystallographic purposes is extremely demanding. Hence, alternative methods to approach the problem of its quaternary structure may be extremely valuable.

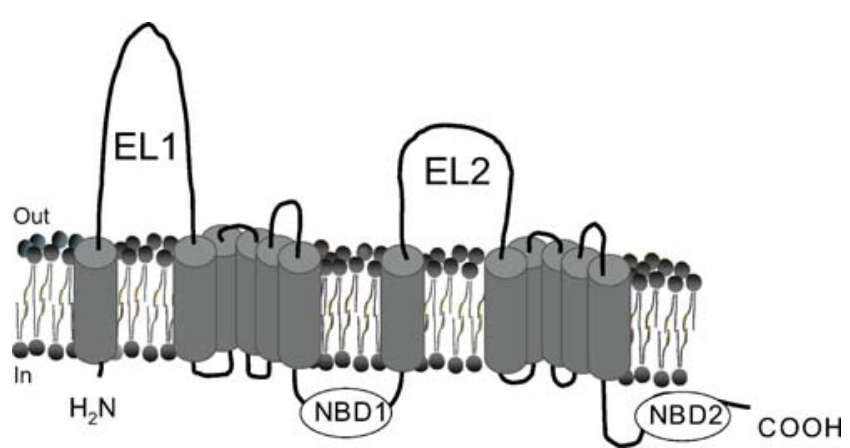

Fig. 1 Schematic view of the topological arrangement of ABCA1. ABCA1 is a full-length transporter with a (TMD-NBD) $)_{2}$ arrangement. The distinctive and hypervariable extracellular loops between TMS1 and TMS2 and between TMS7 and TMS 8 are indicated as EL1 and $E L 2$, respectively. $N B D$, nucleotide binding domain. The intracellular position of the $\mathrm{N}$ and $\mathrm{C}$ terminus is also indicated. The membrane orientation is indicated (In and Out)

\section{Regulation of $\mathrm{ABCA1}$ expression and activity}

Transcriptional control

The essential role played by ABCA1 in reverse cholesterol transport and its identification as a protector against the risk of cardiovascular diseases provoked a profusion of studies to decipher how its expression is controlled both at the transcriptional and posttranscriptional level [90]. ABCA1 expression is highly regulated and implies a variety of molecular actors. For the sake of simplicity, we will discuss them in three major groups: cyclic adenosine monophosphate (cAMP) as an example of secondary messengers; nuclear orphan receptors, the principal controllers of ABCA1 expression; and cytokines, which can exert pleiotropic effects on ABCA1 expression. A schematic overview is given in Fig. 2 and in Table 1.

\section{cAMP}

Cyclic AMP is a ubiquitous second messenger involved in the control of a variety of metabolic events from muscle contraction to memory and in cellular functions such as vesicular secretion and cell growth $[19,38]$. In the case of ABCA1, cAMP up-regulates its expression, by acting both at the transcriptional and translational level. Treatment of mouse macrophage cell lines (RAW 264.7 and J774) with cAMP analogues causes a huge increase in both ABCA1 mRNA and protein levels (estimated at 50- to 70-fold), whereas it has little or no effect on ABCA1 mRNA in human tissue, arguing for different regulation between cell types and species [22, 31, 74]. This effect has been linked to an increased stability of ABCA1 messenger RNA upon cAMP induction. However, the identification of a cAMPresponsive element essential for the induction of ABCA1 gene expression has been reported quite recently. This acts in conjunction with a nearby STAT3/4 element and is not conserved in the human $\mathrm{ABCA} 1$ gene, explaining the lack of cAMP stimulation on human ABCA1 gene [56].

Nuclear orphan receptors

Nuclear receptors are one of the largest groups of transcriptional factors, originally designated as "orphans" as, at that time, the specific ligands were unknown. Nuclear receptors are ligand-dependent transcription factors that regulate numerous aspects of development and homeostasis [6]. The family of nuclear receptors includes liver-X receptor (LXR $\alpha$ and $\beta$ ), retinoic-X receptor (RXR), peroxisome proliferator-activated receptor (PPAR $\alpha, \beta$ and $\gamma$ ), farnesoid-X receptor, pregnane-X receptor (PXR) and thyroid hormone receptor (TR). They are all structurally characterised by an amino-terminal domain responsible 


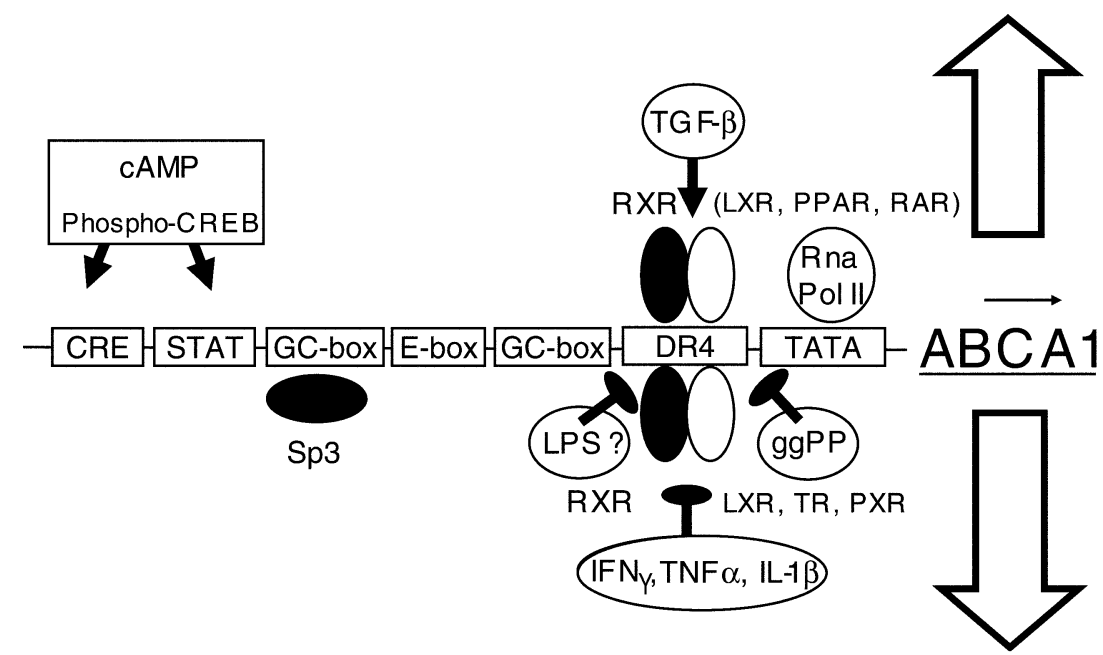

Fig. 2 Transcriptional regulation at the ABCA1 promoter. The diagram schematises the structure of ABCA1 promoter. The factors up-regulating the transcription of ABCA1 gene are indicated above it,

for transcriptional activation and DNA binding and by a carboxy-terminal ligand-binding domain. Among them, LXRs emerge as major regulators of lipid homeostasis. LXRs form obligate heterodimers with RXR and, in this configuration, recognise specific DNA response elements consisting of two direct hexanucleotide repeats separated by four nucleotides (DR4 elements) [26]. Two LXR isoforms exist, LXR $\alpha$ and $\beta$, encoded by different genes. In contrast to LXR $\beta$, which is ubiquitously expressed, the $\alpha$ isoform has a prominent activity in macrophages and liver. The LXR target genes are involved in the whole spectrum of steps crucial in lipid metabolic pathways, from absorption of dietary cholesterol to cellular cholesterol effluxes and reverse cholesterol transport to the metabolism of lipoproteins and the synthesis and esterification of fatty acids [60]. The regulation of cholesterol homeostasis is particularly relevant in macrophages as these cells accumulate massive amounts of cholesterol during the development of atherosclerosis [59]. ABCA1 identification as a sterol sensitive gene is well assessed, both in human and mouse systems, and most of the inductive transcriptional effect of natural or synthetic lipid appears to be mediated via LXRs [20, 90, 103]. The activation of LXR/RXR dimers by physiologically occurring oxysterols, retinoids or their agonists stimulates, via the DR4 element in ABCA1 promoter, the transcription of the gene. This, in turn, leads to an increase in the ABCA1-dependent phospholipid and cholesterol efflux to ApoA-I [21, 52, 70, 111].

The PPAR class of nuclear hormone receptors $(\alpha$ and $\gamma)$ also participates in the up-regulation of ABCA1 expression and reverse cholesterol transport indirectly via enhanced transcription of LXR $\alpha$ [14-16]. The down-regulation of ABCA1 transcription can be achieved through promiscuous whereas below are indicated those down-regulating its expression. For simplicity, the boxes and their positioning along the sequence are not drawn to scale (see Table 1 and [14] for further details)

PXRs activated by a wide variety of compounds including natural and synthetic androgens in prostate cancer cells [90, 96] or through TR/RXR dimers and geranylgeranyl pyrophosphate (ggPP), an intermediate in the endogenous mevalonate pathway [29]. All of these factors act via the DR4 element in the ABCA1 promoter [90].

Crosstalks with immune regulatory pathways

Cytokines have been shown to exert pleiotropic and antinomic effects on ABCA1 transcription. As a general rule, proinflammatory cytokines, tumor necrosis factor $\alpha$ (TNF), interleukin-1 $\beta$ (IL-1 $\beta$ ) and interferon- $\gamma$ down-regulate the LXR-mediated enhancement of ABCA1 transcription and protein expression $[64,76]$, whereas transforming growth factor $\beta$ (TGF $\beta$ ) has the reverse effect and induces ABCA1 expression [77]. These results reinforce the recent findings of multiple crossroads between cellular handling of cholesterol and inflammatory responses mostly mediated at the LXR level. The activation of LXR indeed exerts a global antiinflammatory effect and promotes macrophage survival [13, 41]. Though this is likely to depend on the coordinate activation of multiple sets of genes, it may be worth to investigate whether $\mathrm{ABCA} 1$, as a lipid transporter, is directly instrumental in modulating macrophage responsiveness to activation stimuli [27, 40, 108].

Posttranscriptional modulation of ABCA1 activity

Posttranscriptional regulation plays an important role in the modulation of ABCA1 function by controlling either protein stability and turnover or its activity [62]. The basal regulation of the cellular levels of ABCA1 transporter is 
Table 1 Transcriptional regulation of ABCA1 gene

\begin{tabular}{|c|c|c|c|c|}
\hline Substances & Cell types/tissues & Factors & ABCA1 expression & References \\
\hline \multicolumn{5}{|l|}{ Secondary messengers } \\
\hline Nucleotide analogs & RAW 264.7 J774 & cAMP & + & {$[22,31,56,74]$} \\
\hline \multicolumn{5}{|l|}{ Lipids } \\
\hline Oxysterols LXR agonists & $\begin{array}{l}\text { Macrophages, intestine, liver, } \\
\text { Sertoli cells, neuronal cells }\end{array}$ & $\operatorname{LXR} \alpha, \operatorname{LXR} \beta$ & + & {$[20,25,50,67]$} \\
\hline Retinoids & Macrophages & $\operatorname{RXR} \alpha, \operatorname{RAR} \gamma, \operatorname{LXR} \alpha$ & + & {$[21,52,101,112]$} \\
\hline PPAR $\alpha$-agonists & Macrophages, intestine & PPAR $\alpha$ & + & {$[16,48]$} \\
\hline PPAR $\gamma$-agonists & Macrophages & $\operatorname{PPAR} \gamma$ & + & {$[14,16,61]$} \\
\hline PPAR $\delta$-agonists & THP-1 & PPAR $\delta$ & + & [72] \\
\hline PXR-agonist & HepG2 rat hepatocytes & Rifampicin, LCA, PCN & + & {$[90,96]$} \\
\hline Unsaturated fatty acids & J774, RAW 264.7 & $?$ & - & {$[114,116]$} \\
\hline Cholesterol depletion & HUVEC & SREBP2 & - & [121] \\
\hline Geranylgeranylpyrophosphate & THP-1, CaCo-2 & ggPP, Rho & - & [29] \\
\hline \multicolumn{5}{|l|}{ Hormones } \\
\hline Estrogen & Liver, intestine & $\mathrm{ER} \alpha$ & + & [97] \\
\hline Androgen & $\mathrm{LNCaP}$ & $?$ & - & [28] \\
\hline Thyroid hormone & Fibroblast, $293 \mathrm{~T}$ & TR $\alpha$ & - & [39] \\
\hline \multicolumn{5}{|l|}{ Cytokines } \\
\hline TNF $\alpha$ & $\mathrm{J} 774$ & $?$ & - & {$[47]$} \\
\hline IL-1 $\beta$ & $\mathrm{J} 774$ & $?$ & - & [47] \\
\hline LPS & RAW 264.7 J774 & NF $\kappa \mathrm{B}$ & - & {$[5,47]$} \\
\hline IFN $\gamma$ & Macrophages & STAT1 & - & {$[77,115]$} \\
\hline TGF $\beta$ & Macrophages & $?$ & + & [77] \\
\hline Oncostatin M & HepG2 & $?$ & + & [53] \\
\hline \multicolumn{5}{|l|}{ Drugs } \\
\hline $\mathrm{Aa} 2$ receptor agonist & THP-1 & cAMP & + & {$[80]$} \\
\hline Niacin & MonoMac6 & cAMP, PPAR $\gamma$ & + & [85] \\
\hline Statins & $\begin{array}{l}\text { Macrophages RAW 264.7, } \\
\text { THP-1 }\end{array}$ & $\operatorname{LXR} \alpha$ & $+/-$ & {$[95,118,120]$} \\
\hline Verapamil & RAW 264.7 & $?$ & + & {$[100]$} \\
\hline Bisphosphanate & Macrophages & $?$ & + & [99] \\
\hline \multicolumn{5}{|l|}{ Others } \\
\hline Hypoxia & HUVEC & HIF1 $\alpha /$ ARNT & + & {$[66]$} \\
\hline
\end{tabular}

controlled by calpain-mediated degradation [106], whereas its activity is under the control of diverse protein kinases. Protein kinase A is an effector system that responds to changes in intracellular cAMP. ABCA1 is constitutively phosphorylated by protein kinase A at specific Ser 2054 in the second NBD, in RAW 264.7 macrophages and in transfected human embryonic kidney cell lines. ABCA1 phosphorylation directly modulates its activity and the downstream efflux of phospholipids and cholesterol to the acceptor ApoA-I [92]. It has also been reported that ApoA-I docking at the cell surface may be instrumental in the induction of ABCA1 phosphorylation, through the cAMP/ protein-kinase-A-dependent pathway [32]. Protein kinase CK2 conversely acts as a down-regulator of ABCA1 activity by phosphorylating amino acid residues located downstream of the first NBD [83]. Other regulatory kinases have been reported to contribute to ABCA1-dependent effluxes by acting, however, on targets other than the transporter itself [104].

\section{Expression pattern and intracellular distribution}

Establishing precisely the cellular localisation of ABCA1 and the most relevant functional sites is critical to understand its physiological function. However, the lack of valuable antibodies has prevented a detailed immunohistological description of the ABCA1 expression pattern in the living animal so far. A number of studies in tissues and cell lines have analysed the expression pattern of ABCA1 transcript in human, mouse or baboon via Northern blot, reverse transcriptase-polymerase chain reaction, dot blot or 
in situ hybridisation analysis $[8,17,44,51,54,63,117]$. There is a general consensus toward a wide distribution of ABCA1 mRNA with variation in abundance in specific sites. The highest mRNA expression levels are detected in placenta, pregnant uterus, liver, lung, adrenal glands, heart, small intestine and fetal tissues; the lowest expression is found in pancreas, skeletal muscle, ovary, colon, prostate, mammary glands and bone marrow. The discrepancies concern mainly the level of expression rather than the presence or absence of the transcript.

Wellington et al. [117] have proposed an extensive review of the distribution pattern of mouse ABCA1, taking into account both transcript and protein levels. According to this work, the level of transcript may not accurately predict protein abundance, notably in tissue with intermediate to low abundance of ABCA1 transcript. In conclusion, liver, adrenal glands, testis, pregnant uterus and placenta appear as the major sites of ABCA1 expression. At the cellular level, tissue macrophages as well as macrophage-like cell lines of mouse or human origin are consistently expressing high levels of the transporter. Expression in both liver and macrophage appears of extreme physiological relevance. The expression of ABCA1 on the basolateral membrane of hepatocytes has been shown to indeed contribute significantly to the maintenance of circulating HDL level, in agreement with the prevailing view that the liver is the major site responsible for HDL biogenesis [42, 43]. On the other hand, despite the ubiquitous expression of ABCA1, the accumulation of cholesterol in both human and mouse models of ABCA1 dysfunction occurs principally in macrophages. However, the global amount of lipid efflux from these cells provides only a minimal contribution to circulating HDL levels. The progression of foam cell formation and the atheroma development are consistently significantly influenced by the ABCAl expression on macrophages but largely independent of the levels of circulating $\operatorname{HDL}[1,2,30]$.

At the cellular level, ABCA1 is predominantly located on the plasma membrane. It is currently thought that this localisation is necessary and sufficient for its function as a promoter of lipid effluxes. On the other hand, ABCA1EGFP chimeras also decorate the endo-lysosomal compartment $[34,82,88]$ from where they can actively shuttle to the plasma membrane $[71,88]$. This may be relevant for the control of cellular lipid handling considering the endocytic recycling of cell-bound apoproteins. Takahashi and Smith [102] reported that uptake and resecretion of ApoA-I indeed occur via endocytic vesicles (retroendocytosis) where ApoA-I and ABCA1-EGFP could co-localise. Thus, in line with these results, it may be envisioned that ABCA1 not only mediates lipid desorption at the cell surface but, upon internalisation, may also pump lipids into the vesicular lumen. Those would associate with the endocytosed apoproteins there and be further released as mature HDL particles upon fusion of the vesicle with the plasma membrane [7] (Fig. 3).

\section{ABCA1 and disease: human genetic and mouse models}

The mutations in the ABCA1 transporter gene have been identified as the molecular defect responsible for Tangier disease, an autosomic recessive disorder of lipid metabolism $[10,55,86,87]$. The clinical hallmarks of Tangier disease include the virtual absence of circulating HDL and ApoA-I. These are associated to a whole spectrum of signs, from orange tonsils, peripheral neuropathy, splenomegaly to thrombocytopenia and increased incidence of cardiovascular disease, whose clinical penetrance is however extremely variable [4]. Seminal to these signs is an impairment of cellular effluxes of phospholipids and cholesterol to lipid-poor apolipoproteins, diagnostic of Tangier disease among the other forms of hypoalphalipoproteinemias [4]. The mutations of ABCA1 have also been detected in a nosographically distinct disorder of HDL deficiency, familial HDL deficiency, that is clinically superimposable to Tangier disease but is transmitted as a dominant trait. This discrepancy may find its origin in the recent notion that ABCA1 assembly into oligomeric structures is required for full functional competence. We have indeed recently applied biophysical methods such as intermolecular fluorescence resonance energy transfer [46] and biochemical methods such as electrophoretic analysis in native condition (native polyacrylamide gel electrophoresis) [78] to the study of ABCA1 molecular assembly.

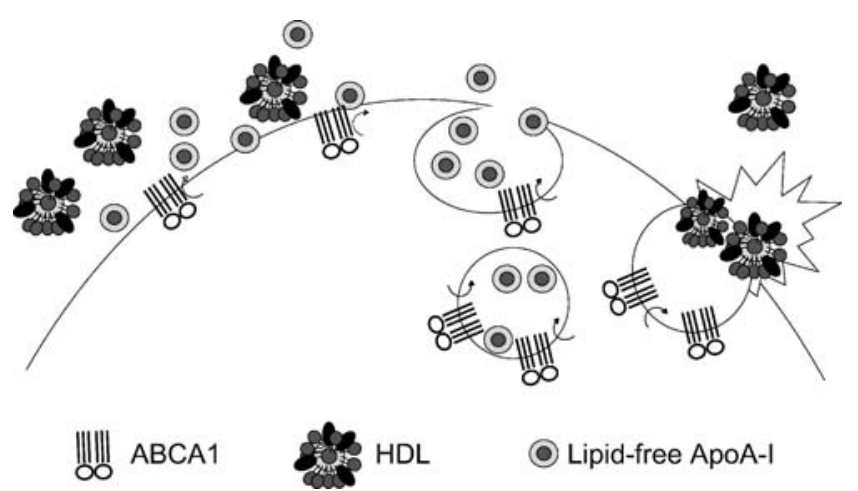

Fig. 3 Retroendocytosis as a source of newly formed HDL particles. Surface bound-ApoA-I is endocytosed and meets ABCA1 in recycling endosomes. From there, a retrograde secretion, reminiscent of receptor-ligand retroendocytosis, takes place. The ABCA1-dependent lipid desorption generates, in the vesicular lumen, lipidated ApoA-I particles and then fully mature HDL. The latter particles are secreted by vesicular fusion with the plasma membrane. Arrows schematise the lipid translocator function of ABCA1 
These studies have provided evidence that ABCA1 is predominantly expressed as a dimer and that the transition between oligomeric states is part of its enzymatic cycle (Trompier et al., submitted for publication). Thus, the mutations specifically impairing oligomerisation would show a transdominant negative effect and the associated phenotypic abnormalities would be transmitted genetically as dominant traits.

An investigation on the relationship between discrete mutation and phenotype may also be instrumental in understanding what governs the variable penetrance of clinical signs in Tangier pedigrees. As direct genotype/ phenotype correlations are impossible due to the rarity of the disease (60 pedigrees reported as for now) [94], alternative approaches such as the generation of appropriate animal models exclusively expressing informative ABCA 1 mutants have to be envisioned. Finally, as ABCA1 can be considered one of the most clearly identified therapeutic targets in the prevention of cardiovascular disease [58, 73], several efforts have arisen in the aim of predicting how and whether genetic polymorphism may contribute to differences in phenotypic traits $[11,79]$.

The generation of knockout mice irrevocably demonstrated that ABCA1 dysfunction is sufficient to generate hypolipidemic profiles $[17,34,68,75]$. These mice faithfully reproduce the human syndrome; however, a few traits appear limited to the mouse models. First, the engulfment of cells dying by apoptosis is clearly impaired during embryonic development in the mice [34]. This defect, which is devoid of major developmental consequences, has obviously not been investigated in humans. In addition, ABCA1-/- females are infertile due to impaired placental development, a phenotype related to the high expression level of ABCA1 in the pregnant uterus [17, 75]. A similar sign is lacking in human Tangier patients though an increased incidence of spontaneous abortions has been informally recorded.

The availability of animal models carrying the invalidation of ABCA1 gene has prompted a large body of work to be targeted at the definition of the protective role of the transporter in the development of atheroma lesion. Though the results globally confirm the predicted protective effect, a number of inconsistencies can be observed [42]. These are likely to originate from the heterogeneity of genetic backgrounds used in the different experimental setups. Though the alterations in metabolic profile and most phenotypes related to ABCA1 loss of function appear robust and background-insensitive, exquisite differences in the ABCA1 expression indeed exist between the various mouse strains (Trompier, unpublished results) [65]. This together with the well-known genetically determined differences in the cytokine regime and the activation of immunoregulatory pathways may well contribute to blur the experimental results obtained from heterogeneous sources.

The invalidation of ABCA1 gene in mice leads also to clinically relevant phenotypes unrelated to lipid metabolism; these span from aberrant responses to malaria infection to increased development of Alzheimer's related degenerative lesions. In ABCA1-/- mice, generated in the pure DBA1/J background, the infection with Plasmodium berghei ANKA indeed leads to a robust resistance to the development of fatal cerebral malaria [18]. This can be traced to a reduced activation of macrophages in response to Plasmodium antigens as very low levels of circulating TNF $\alpha$ and plasma microparticles were observed. Modified macrophages polarisation, consequent to the ABCA1 deletion, may hence be envisioned and is indeed supported by the exquisite responses of ABCA1-/- myelomonocytic lineages to inflammatory stimuli and cytokine activation (Broccardo, unpublished results). The development of crosses between ABCA1 deleted mice and Alzheimer's prone models, in heterogeneous genetic backgrounds, more recently revealed that the absence of the transporter induces an aggravation of fibrillar amyloid deposit [35, 49, 113]. This may be related directly not only to the ABCA1 function as a provider of lipid to nascent HDL-like particles in the brain but also to the fact that cholesterol content/ distribution in ABCA1-/- membranes is greatly altered. It is known that the amyloidogenic proteolysis of Alzheimer's precursor protein is indeed largely determined by its partitioning in/out membrane microdomains [37].

In this respect, it may be worth mentioning that the sorting of ABCA1 in specialised membrane domains is still a controversial issue. In our hands and at odds with previous results $[23,69]$, the experimental evidence indicates that a substantial fraction of the transporter is located in Lubrol WX and Brij 98 insoluble membrane domains while largely excluded from the classical "core microdomains" defined as Triton X-100 insoluble (Zarubica, unpublished observation). This finding has been quite recently supported by the lipidomic analysis of ABCA1generated membrane microvesicles, clearly indicating that a conspicuous proportion derives from membrane microdomains [24]. Thus, irrespective of the transporter partitioning in the liquid-ordered or liquid-disordered membrane phases, its ability to facilitate desorption of membrane phospholipids and cholesterol may be expected to have consequences on the lateral arrangement of membrane lipids and on the sorting of proteins [84].

\section{ABC transporters in lipid homeostasis}

The shedding of lipid from cell membranes is a ubiquitous event. In most cases, it concerns the transport of a specific 


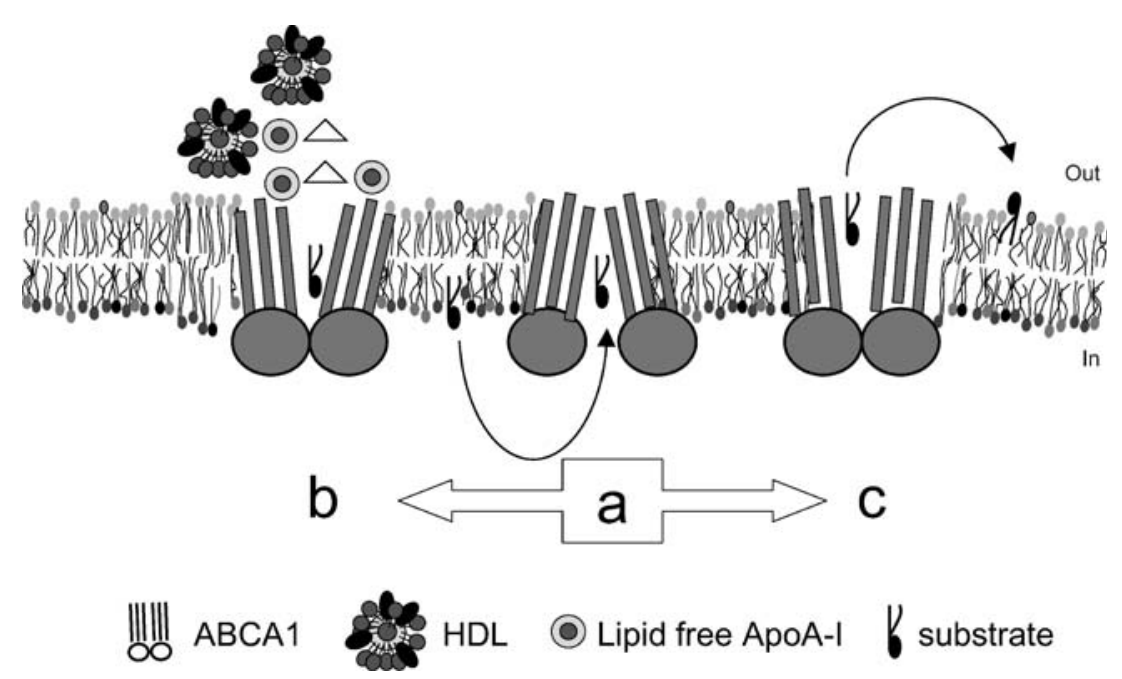

Fig. 4 Bimodal functioning of ABCA1 as a lipid translocator. a The ABCA1 substrate (black) is translocated, at minimal energetic expense, in the internal core of the transporter. No rotation of the lipid headgroup is required. The lipid can now either be desorbed in the same orientation on the acceptor ApoA-I (b) and follow the routing to HDL formation

monomer form of lipid from one leaflet of the membrane to the other or to an external acceptor. Many human diseases have been related to defective desorption of lipids from cell membranes and, in nearly all cases, members of the $\mathrm{ABC}$ transporter family appear at the origin of defect [110]. In their vast majority, they belong to the A, D and G classes $[3,36]$ and dedicated reviews in this issue]. The $\mathrm{D}$ class includes half-transporters localised at the membrane of the peroxisome and involved in peroxisome biogenesis and/or in the transport of fatty acids across the membrane of these organelles [105]. Apart from ABCA1, most of the A class members are supposed to transport lipid substrates from the cytosol to either the exofacial leaflet of the membrane or the extracellular space or onto specialised membranes in intracellular organelles [45, 93, 107]. Four out the ABCG hemitransporters have been implicated in the transport of sterols, either in the intestine where ABCG5 and ABCG8 pump back absorbed sterols into the gut lumen [119] or in macrophages and liver cells where ABCG1 and ABCG4 work in concert with ABCA1 to actively transport cholesterol to mature HDL [91].

In all of these cases, the direct evidence addressing the transport itself and the substrate specificity is relatively limited, though the latter one seems to be quite diverse among the different members. How this is controlled and more generally how transport occurs in mechanistic terms are still open questions. Several models have been suggested: from the classical flippase model to the refined variation recently proposed by van Meer et al. [110] (Fig. 4). This latter proposal suggests that the lipids could be translocated without undergoing reorientation of their (arrowheads) or, in the absence of the acceptor, be flipped to the external membrane leaflet (c) [110]. The movements of the lipid substrate are schematised by the arrows. The inner and outer leaflets of the membrane are indicated

headgroups, from the inner membrane leaflet to the internal core of the transporter. From there, it can either be released onto an external acceptor or, in its absence, be reoriented, at energetic expenses, in the exofacial membrane leaflet. In other words, for example in our case, ABCA1 could either pump the phospholipid substrates onto apoprotein acceptors docked in its close proximity or flip them into the external leaflet of the membrane. This model has the distinctive advantage to solve some of the incongruence of the more classical flippase model, such as the evident need for acceptors or the energetic demand required for release of lipid substrates into aqueous medium. In addition, this bimodal and non-exclusive model can easily accommodate molecular partners acting as regulators of extrusion vs membrane flipping.

Acknowledgements This work has been funded by institutional grants from INSERM and CNRS and specific grants from the European Community. DT was funded by the Nouvelle Société Françdise d' Athérosclérose/Fournier Pharma.

\section{References}

1. Aiello RJ, Brees D, Francone OL (2003) ABCA1-deficient mice: insights into the role of monocyte lipid efflux in HDL formation and inflammation. Arterioscler Thromb Vasc Biol 23:972-980

2. Aiello RJ, Brees D, Bourassa PA, Royer L, Lindsey S, Coskran T, Haghpassand M, Francone OL (2002) Increased atherosclerosis in hyperlipidemic mice with inactivation of ABCA1 in macrophages. Arterioscler Thromb Vasc Biol 22:630-637

3. Albrecht C, Viturro E (2006) The ABCA subfamily — gene and protein structures, functions and associated hereditary diseases. Pflugers Arch (In press) 
4. Assmann G, von Eckardstein A, Brewer HB (2001) Familial analphalipoproteinemia: Tangier disease. In: Scriver CR, Beaudet AL, Sly WS, Valle D (eds) The metabolic basis of inherited disease. McGraw-Hill, New York, pp 2937-2960

5. Baranova I, Vishnyakova T, Bocharov A, Chen Z, Remaley AT, Stonik J, Eggerman TL, Patterson AP (2002) Lipopolysaccharide down regulates both scavenger receptor B1 and ATP binding cassette transporter A1 in RAW cells. Infect Immun 70:2995-3003

6. Beaven SW, Tontonoz P (2006) Nuclear receptors in lipid metabolism: targeting the heart of dyslipidemia. Annu Rev Med 57:313-329

7. Boadu E, Francis GA (2006) The role of vesicular transport in ABCA1-dependent lipid efflux and its connection with NPC pathways. J Mol Med 84:266-275

8. Bortnick AE, Rothblat GH, Stoudt G, Hoppe KL, Royer LJ, McNeish J, Francone OL (2000) The correlation of ATP-binding cassette $1 \mathrm{mRNA}$ levels with cholesterol efflux from various cell lines. J Biol Chem 275:28634-28640

9. Broccardo C, Osorio J, Luciani MF, Schriml LM, Prades C, Shulenin S, Arnould I, Naudin L, Lafargue C, Rosier M, Jordan B, Mattei MG, Dean M, Denefle P, Chimini G (2001) Comparative analysis of the promoter structure and genomic organization of the human and mouse $\mathrm{ABCA} 7$ gene encoding a novel ABCA transporter. Cytogenet Cell Genet 92:264-270

10. Brooks-Wilson A, Marcil M, Clee SM, Zhang LH, Roomp K, van Dam M, Yu L, Brewer C, Collins JA, Molhuizen HO, Loubser O, Ouelette BF, Fichter K, Ashbourne-Excoffon KJ, Sensen CW, Scherer S, Mott S, Denis M, Martindale D, Frohlich J, Morgan K, Koop B, Pimstone S, Kastelein JJ, Genest J Jr, Hayden MR (1999) Mutations in $\mathrm{ABC} 1$ in Tangier disease and familial high-density lipoprotein deficiency. Nat Genet 22:336-345

11. Brunham LR, Singaraja RR, Pape TD, Kejariwal A, Thomas PD, Hayden MR (2005) Accurate prediction of the functional significance of single nucleotide polymorphisms and mutations in the ABCA1 gene. PLoS Genet 1:e83

12. Bungert S, Molday LL, Molday RS (2001) Membrane topology of the ATP binding cassette transporter ABCR and its relationship to $\mathrm{ABC} 1$ and related $\mathrm{ABCA}$ transporters. J Biol Chem 276:23539-23546

13. Castrillo A, Joseph SB, Vaidya SA, Haberland M, Fogelman AM, Cheng G, Tontonoz P (2003) Crosstalk between LXR and toll-like receptor signaling mediates bacterial and viral antagonism of cholesterol metabolism. Mol Cell 12:805-816

14. Chawla A, Boisvert WA, Lee CH, Laffitte BA, Barak Y, Joseph SB, Liao D, Nagy L, Edwards PA, Curtiss LK, Evans RM, Tontonoz P (2001) A PPAR gamma-LXR-ABCA1 pathway in macrophages is involved in cholesterol efflux and atherogenesis. Mol Cell 7:161-171

15. Chinetti-Gbaguidi G, Rigamonti E, Helin L, Mutka AL, Lepore M, Fruchart JC, Clavey V, Ikonen E, Lestavel S, Staels B (2005) Peroxisome proliferator-activated receptor alpha controls cellular cholesterol trafficking in macrophages. J Lipid Res 46:2717-2725

16. Chinetti G, Lestavel S, Bocher V, Remaley AT, Neve B, Torra IP, Teissier E, Minnich A, Jaye M, Duverger N, Brewer HB, Fruchart JC, Clavey V, Staels B (2001) PPAR-alpha and PPARgamma activators induce cholesterol removal from human macrophage foam cells through stimulation of the ABCA1 pathway. Nat Med 7:53-58

17. Christiansen-Weber TA, Voland JR, Wu Y, Ngo K, Roland BL, Nguyen S, Peterson PA, Fung-Leung WP (2000) Functional loss of ABCA1 in mice causes severe placental malformation, aberrant lipid distribution, and kidney glomerulonephritis as well as high-density lipoprotein cholesterol deficiency. Am J Pathol 157:1017-1029
18. Combes V, Coltel N, Alibert M, van Eck M, Raymond C, Juhan-Vague I, Grau GE, Chimini G (2005) ABCA1 gene deletion protects against cerebral malaria: potential pathogenic role of microparticles in neuropathology. Am J Pathol 166:295-302

19. Cooper DM (2003) Regulation and organization of adenylyl cyclases and cAMP. Biochem J 375:517-529

20. Costet P, Luo Y, Wang N, Tall AR (2000) Sterol-dependent transactivation of the human $\mathrm{ABC} 1$ promoter by LXR/ RXR. J Biol Chem 275:28240-28245

21. Costet P, Lalanne F, Gerbod-Giannone MC, Molina JR, Fu X, Lund EG, Gudas LJ, Tall AR (2003) Retinoic acid receptormediated induction of ABCA1 in macrophages. Mol Cell Biol 23:7756-7766

22. Denis M, Bissonnette R, Haidar B, Krimbou L, Bouvier M, Genest J (2003) Expression, regulation, and activity of ABCA1 in human cell lines. Mol Genet Metab 78:265-274

23. Drobnik W, Borsukova H, Bottcher A, Pfeiffer A, Liebisch G, Schutz GJ, Schindler H, Schmitz G (2002) Apo AI/ABCA1dependent and HDL3-mediated lipid efflux from compositionally distinct cholesterol-based microdomains. Traffic 3:268-278

24. Duong PT, Collins HL, Nickel M, Lund-Katz S, Rothblat GH, Phillips MC (2006) Characterization of nascent HDL particles and microparticles formed by ABCA1-mediated efflux of cellular lipids to ApoA-I. J Lipid Res 47:832-843

25. Field FJ, Born E, Mathur SN (2004) LXR/RXR ligand activation enhances basolateral efflux of beta-sitosterol in CaCo-2 cells. J Lipid Res 45:905-913

26. Fitzgerald ML, Moore KJ, Freeman MW (2002) Nuclear hormone receptors and cholesterol trafficking: the orphans find a new home. J Mol Med 80:271-281

27. Freeman MW, Moore KJ (2003) eLiXiRs for restraining inflammation. Nat Med 9:168-169

28. Fukuchi J, Hiipakka RA, Kokontis JM, Hsu S, Ko AL, Fitzgerald ML, Liao S (2004) Androgenic suppression of ATPbinding cassette transporter $\mathrm{A} 1$ expression in $\mathrm{LNCaP}$ human prostate cancer cells. Cancer Res 64:7682-7685

29. Gan X, Kaplan R, Menke JG, MacNaul K, Chen Y, Sparrow CP, Zhou G, Wright SD, Cai TQ (2001) Dual mechanisms of ABCA1 regulation by geranylgeranyl pyrophosphate. J Biol Chem 276:48702-48708

30. Haghpassand M, Bourassa PA, Francone OL, Aiello RJ (2001) Monocyte/macrophage expression of ABCA1 has minimal contribution to plasma HDL levels. J Clin Invest 108:1315-1320

31. Haidar B, Denis M, Krimbou L, Marcil M, Genest J Jr (2002) cAMP induces ABCA1 phosphorylation activity and promotes cholesterol efflux from fibroblasts. J Lipid Res 43:2087-2094

32. Haidar B, Denis M, Marcil M, Krimbou L, Genest J Jr (2004) Apolipoprotein A-I activates cellular cAMP signaling through the ABCA1 transporter. J Biol Chem 279:9963-9969

33. Hamon Y, Chambenoit O, Chimini G (2002) ABCA1 and the engulfment of apoptotic cells. Biochim Biophys Acta 1585:64-71

34. Hamon Y, Broccardo C, Chambenoit O, Luciani MF, Toti F, Chaslin S, Freyssinet JM, Devaux PF, McNeish J, Marguet D, Chimini G (2000) ABC1 promotes engulfment of apoptotic cells and transbilayer redistribution of phosphatidylserine. Nat Cell Biol 2:399-406

35. Hirsch-Reinshagen V, Maia LF, Burgess BL, Blain JF, Naus KE, McIsaac SA, Parkinson PF, Chan JY, Tansley GH, Hayden MR, Poirier J, Van Nostrand W, Wellington CL (2005) The absence of ABCA1 decreases soluble ApoE levels but does not diminish amyloid deposition in two murine models of Alzheimer disease. J Biol Chem 280:43243-43256 
36. Holland IB, Cole SPC, Kuchler K, Higgins CF (eds) (2003) $\mathrm{ABC}$ proteins. From bacteria to man. Academic, London, San Diego

37. Hooper NM (2005) Roles of proteolysis and lipid rafts in the processing of the amyloid precursor protein and prion protein. Biochem Soc Trans 33:335-338

38. Houslay MD, Kolch W (2000) Cell-type specific integration of cross-talk between extracellular signal-regulated kinase and cAMP signaling. Mol Pharmacol 58:659-668

39. Huuskonen J, Vishnu M, Pullinger CR, Fielding PE, Fielding CJ (2004) Regulation of ATP-binding cassette transporter A1 transcription by thyroid hormone receptor. Biochemistry 43:1626-1632

40. Joseph SB, Castrillo A, Laffitte BA, Mangelsdorf DJ, Tontonoz $P$ (2003) Reciprocal regulation of inflammation and lipid metabolism by liver X receptors. Nat Med 9:213-219

41. Joseph SB, Bradley MN, Castrillo A, Bruhn KW, Mak PA, Pei L, Hogenesch J, O'Connell RM, Cheng G, Saez E, Miller JF, Tontonoz P (2004) LXR-dependent gene expression is important for macrophage survival and the innate immune response. Cell 119:299-309

42. Joyce C, Freeman L, Brewer HB Jr, Santamarina-Fojo S (2003) Study of ABCA1 function in transgenic mice. Arterioscler Thromb Vasc Biol 23:965-971

43. Joyce CW, Amar MJ, Lambert G, Vaisman BL, Paigen B, NajibFruchart J, Hoyt RF Jr, Neufeld ED, Remaley AT, Fredrickson DS, Brewer HB Jr, Santamarina-Fojo S (2002) The ATP binding cassette transporter A1 (ABCA1) modulates the development of aortic atherosclerosis in C57BL/6 and apoE-knockout mice. Proc Natl Acad Sci USA 99:407-412

44. Kaminski WE, Orso E, Diederich W, Klucken J, Drobnik W, Schmitz G (2000) Identification of a novel human sterolsensitive ATP-binding cassette transporter (ABCA7). Biochem Biophys Res Commun 273:532-538

45. Kelsell DP, Norgett EE, Unsworth H, Teh MT, Cullup T, Mein CA, Dopping-Hepenstal PJ, Dale BA, Tadini G, Fleckman P, Stephens KG, Sybert VP, Mallory SB, North BV, Witt DR, Sprecher E, Taylor AE, Ilchyshyn A, Kennedy CT, Goodyear H, Moss C, Paige D, Harper JI, Young BD, Leigh IM, Eady RA, O'Toole EA (2005) Mutations in ABCA12 underlie the severe congenital skin disease harlequin ichthyosis. Am J Hum Genet 76:794-803

46. Kenworthy AK, Petranova N, Edidin M (2000) High-resolution FRET microscopy of cholera toxin B-subunit and GPIanchored proteins in cell plasma membranes. Mol Biol Cell $11: 1645-1655$

47. Khovidhunkit W, Moser AH, Shigenaga JK, Grunfeld C, Feingold KR (2003) Endotoxin down-regulates ABCG5 and ABCG8 in mouse liver and ABCA1 and ABCG1 in J774 murine macrophages: differential role of LXR. J Lipid Res 44:1728-1736

48. Knight BL, Patel DD, Humphreys SM, Wiggins D, Gibbons GF (2003) Inhibition of cholesterol absorption associated with a PPAR alpha-dependent increase in ABC binding cassette transporter A1 in mice. J Lipid Res 44:2049-2058

49. Koldamova R, Staufenbiel M, Lefterov I (2005) Lack of ABCA1 considerably decreases brain ApoE level and increases amyloid deposition in APP23 mice. J Biol Chem 280:43224-43235

50. Koldamova RP, Lefterov IM, Ikonomovic MD, Skoko J, Lefterov PI, Isanski BA, DeKosky ST, Lazo JS (2003) 22R-hydroxycholesterol and 9-cis-retinoic acid induce ATP-binding cassette transporter A1 expression and cholesterol efflux in brain cells and decrease amyloid beta secretion. J Biol Chem 278:13244-13256

51. Langmann T, Klucken J, Reil M, Liebisch G, Luciani MF, Chimini G, Kaminski WE, Schmitz G (1999) Molecular cloning of the human ATP-binding cassette transporter 1 (hABC1): evidence for sterol-dependent regulation in macrophages. Biochem Biophys Res Commun 257:29-33
52. Langmann T, Liebisch G, Moehle C, Schifferer R, Dayoub R, Heiduczek S, Grandl M, Dada A, Schmitz G (2005) Gene expression profiling identifies retinoids as potent inducers of macrophage lipid efflux. Biochim Biophys Acta 1740: $\quad 155-161$

53. Langmann T, Porsch-Ozcurumez M, Heimerl S, Probst M, Moehle C, Taher M, Borsukova H, Kielar D, Kaminski WE, Dittrich-Wengenroth E, Schmitz G (2002) Identification of sterol-independent regulatory elements in the human ATPbinding cassette transporter A1 promoter: role of Sp1/3, E-box binding factors, and an oncostatin M-responsive element. J Biol Chem 277:14443-14450

54. Lawn RM, Wade DP, Couse TL, Wilcox JN (2001) Localization of human atp-binding cassette transporter 1 (abc1) in normal and atherosclerotic tissues. Arterioscler Thromb Vasc Biol 21:378-385

55. Lawn RM, Wade DP, Garvin MR, Wang X, Schwartz K, Porter JG, Seilhamer JJ, Vaughan AM, Oram JF (1999) The tangier disease gene product $\mathrm{ABC} 1$ controls the cellular apolipoproteinmediated lipid removal pathway. J Clin Invest 104:R25-R31

56. Le Goff W, Zheng P, Brubaker G, Smith JD (2006) Identification of the cAMP-responsive enhancer of the murine ABCA1 gene. Requirement for CREB1 and STAT3/4 elements. Arterioscler Thromb Vasc Biol 26:527-533

57. Lee JY, Parks JS (2005) ATP-binding cassette transporter AI and its role in HDL formation. Curr Opin Lipidol 16:19-25

58. Lewis GF, Rader DJ (2005) New insights into the regulation of HDL metabolism and reverse cholesterol transport. Circ Res 96:1221-1232

59. Li AC, Glass CK (2002) The macrophage foam cell as a target for therapeutic intervention. Nat Med 8:1235-1242

60. Li AC, Glass CK (2004) PPAR- and LXR-dependent pathways controlling lipid metabolism and the development of atherosclerosis. J Lipid Res 45:2161-2173

61. Li AC, Binder CJ, Gutierrez A, Brown KK, Plotkin CR, Pattison JW, Valledor AF, Davis RA, Willson TM, Witztum JL, Palinski W, Glass CK (2004) Differential inhibition of macrophage foamcell formation and atherosclerosis in mice by PPARalpha, beta/ delta, and gamma. J Clin Invest 114:1564-1576

62. Llaverias G, Lacasa D, Vazquez-Carrera M, Sanchez RM, Laguna JC, Alegret M (2005) Cholesterol regulation of genes involved in sterol trafficking in human THP-1 macrophages. Mol Cell Biochem 273:185-191

63. Luciani MF, Denizot F, Savary S, Mattei MG, Chimini G (1994) Cloning of two novel ABC transporters mapping on human chromosome 9. Genomics 21:150-159

64. Lusis AJ (2000) Atherosclerosis. Nature 407:233-241

65. Lyons MA, Wittenburg H, Li R, Walsh KA, Churchill GA, Carey MC, Paigen B (2003) Quantitative trait loci that determine lipoprotein cholesterol levels in DBA/2J and CAST/Ei inbred mice. J Lipid Res 44:953-967

66. Manalo DJ, Rowan A, Lavoie T, Natarajan L, Kelly BD, Ye SQ, Garcia JG, Semenza GL (2005) Transcriptional regulation of vascular endothelial cell responses to hypoxia by HIF-1. Blood 105:659-669

67. Mascrez B, Ghyselinck NB, Watanabe M, Annicotte JS, Chambon P, Auwerx J, Mark M (2004) Ligand-dependent contribution of RXRbeta to cholesterol homeostasis in Sertoli cells. EMBO Rep 5:285-290

68. McNeish J, Aiello RJ, Guyot D, Turi T, Gabel C, Aldinger C, Hoppe KL, Roach ML, Royer LJ, de Wet J, Broccardo C, Chimini G, Francone OL (2000) High density lipoprotein deficiency and foam cell accumulation in mice with targeted disruption of ATP-binding cassette transporter-1. Proc Natl Acad Sci USA 97:4245-4250 
69. Mendez AJ, Lin G, Wade DP, Lawn RM, Oram JF (2001) Membrane lipid domains distinct from cholesterol/sphingomyelin-rich rafts are involved in the ABCA1-mediated lipid secretory pathway. J Biol Chem 276:3158-3166

70. Murthy S, Born E, Mathur SN, Field FJ (2002) LXR/RXR activation enhances basolateral efflux of cholesterol in $\mathrm{CaCo}-2$ cells. J Lipid Res 43:1054-1064

71. Neufeld EB, Remaley AT, Demosky SJ, Stonik JA, Cooney AM, Comly M, Dwyer NK, Zhang M, Blanchette-Mackie J, Santamarina-Fojo S, Brewer HB (2001) Cellular localization and trafficking of the human ABCA1 transporter. J Biol Chem 276:27584-27590

72. Oliver WR Jr, Shenk JL, Snaith MR, Russell CS, Plunket KD, Bodkin NL, Lewis MC, Winegar DA, Sznaidman ML, Lambert MH, Xu HE, Sternbach DD, Kliewer SA, Hansen BC, Willson TM (2001) A selective peroxisome proliferator-activated receptor delta agonist promotes reverse cholesterol transport. Proc Natl Acad Sci USA 98:5306-5311

73. Oram JF, Heinecke JW (2005) ATP-binding cassette transporter A1: a cell cholesterol exporter that protects against cardiovascular disease. Physiol Rev 85:1343-1372

74. Oram JF, Lawn RM, Garvin MR, Wade DP (2000) ABCA1 is the cAMP-inducible apolipoprotein receptor that mediates cholesterol secretion from macrophages. J Biol Chem 275:34508-34511

75. Orso E, Broccardo C, Kaminski WE, Bottcher A, Liebisch G, Drobnik W, Gotz A, Chambenoit O, Diederich W, Langmann T, Spruss T, Luciani MF, Rothe G, Lackner KJ, Chimini G, Schmitz G (2000) Transport of lipids from golgi to plasma membrane is defective in tangier disease patients and Abc1-deficient mice. Nat Genet 24:192-196

76. Panousis CG, Zuckerman SH (2000) Interferon-gamma induces downregulation of Tangier disease gene (ATP-binding-cassette transporter 1) in macrophage-derived foam cells. Arterioscler Thromb Vasc Biol 20:1565-1571

77. Panousis CG, Evans G, Zuckerman SH (2001) TGF-beta increases cholesterol efflux and $\mathrm{ABC}-1$ expression in macrophage-derived foam cells: opposing the effects of IFN-gamma. J Lipid Res 42:856-863

78. Peter GF, Thornber JP (1991) Biochemical composition and organization of higher plant photosystem II light-harvesting pigment-proteins. J Biol Chem 266:16745-16754

79. Probst MC, Thumann H, Aslanidis C, Langmann T, Buechler C, Patsch W, Baralle FE, Dallinga-Thie GM, Geisel J, Keller C, Menys VC, Schmitz G (2004) Screening for functional sequence variations and mutations in ABCA1. Atherosclerosis 175:269-279

80. Reiss AB, Rahman MM, Chan ES, Montesinos MC, Awadallah NW, Cronstein BN (2004) Adenosine A2A receptor occupancy stimulates expression of proteins involved in reverse cholesterol transport and inhibits foam cell formation in macrophages. J Leukoc Biol 76:727-734

81. Remaley AT, Rust S, Rosier M, Knapper C, Naudin L, Broccardo C, Peterson KM, Koch C, Arnould I, Prades C, Duverger N, Funke H, Assman G, Dinger M, Dean M, Chimini G, Santamarina-Fojo S, Fredrickson DS, Denefle P, Brewer HB Jr (1999) Human ATP-binding cassette transporter 1 (ABC1): genomic organization and identification of the genetic defect in the original Tangier disease kindred. Proc Natl Acad Sci USA 96:12685-12690

82. Rigot V, Hamon Y, Chambenoit O, Alibert M, Duverger N, Chimini G (2002) Distinct sites on ABCA1 control distinct steps required for cellular release of phospholipids. J Lipid Res 43:2077-2086

83. Roosbeek S, Peelman F, Verhee A, Labeur C, Caster H, Lensink MF, Cirulli C, Grooten J, Cochet C, Vandekerckhove J, Amoresano A, Chimini G, Tavernier J, Rosseneu M (2004)
Phosphorylation by protein kinase CK2 modulates the activity of the ATP binding cassette A1 transporter. J Biol Chem 279:37779-37788

84. Roux A, Cuvelier D, Nassoy P, Prost J, Bassereau P, Goud B (2005) Role of curvature and phase transition in lipid sorting and fission of membrane tubules. EMBO J 24:1537-1545

85. Rubic T, Trottmann M, Lorenz RL (2004) Stimulation of CD36 and the key effector of reverse cholesterol transport ATP-binding cassette A1 in monocytoid cells by niacin. Biochem Pharmacol 67:411-419

86. Rust S, Rosier M, Funke H, Real J, Amoura Z, Piette JC, Deleuze JF, Brewer HB, Duverger N, Denefle P, Assmann G (1999) Tangier disease is caused by mutations in the gene encoding ATP-binding cassette transporter 1. Nature Genet 22:352-355

87. Rust S, Walter M, Funke H, von Eckardstein A, Cullen P, Kroes H, Hordijk R, Geisel J, Kastelein J, Molhuizen H, Schreiner M, Mischke A, Hahmann H, Assmann G (1998) Assignment of Tangier disease to chromosome $9 \mathrm{q} 31$ by a graphical linkage exclusion strategy. Nat Genet 20:96-98

88. Santamarina-Fojo S, Remaley AT, Neufeld EB, Brewer HB Jr (2001) Regulation and intracellular trafficking of the ABCA1 transporter. J Lipid Res 42:1339-1345

89. Santamarina-Fojo S, Peterson K, Knapper C, Qiu Y, Freeman L, Cheng JF, Osorio J, Remaley A, Yang XP, Haudenschild C, Prades C, Chimini G, Blackmon E, Francois T, Duverger N, Rubin EM, Rosier M, Denefle P, Fredrickson DS, Brewer HB Jr (2000) Complete genomic sequence of the human ABCA1 gene: analysis of the human and mouse ATP-binding cassette A promoter. Proc Natl Acad Sci USA 97:7987-7992

90. Schmitz G, Langmann $\mathrm{T}$ (2005) Transcriptional regulatory networks in lipid metabolism control ABCA1 expression. Biochim Biophys Acta 1735:1-19

91. Schmitz G, Langmann T, Heimerl S (2001) Role of ABCG1 and other ABCG family members in lipid metabolism. J Lipid Res 42:1513-1520

92. See RH, Caday-Malcolm RA, Singaraja RR, Zhou S, Silverston A, Huber MT, Moran J, James ER, Janoo R, Savill JM, Rigot V, Zhang LH, Wang M, Chimini G, Wellington CL, Tafuri SR, Hayden MR (2002) Protein kinase A site-specific phosphorylation regulates ATP-binding cassette A1 (ABCA1)-mediated phospholipid efflux. J Biol Chem 277:41835-41842

93. Shulenin S, Nogee LM, Annilo T, Wert SE, Whitsett JA, Dean M (2004) ABCA3 gene mutations in newborns with fatal surfactant deficiency. N Engl J Med 350:1296-1303

94. Singaraja RR, Brunham LR, Visscher H, Kastelein JJ, Hayden MR (2003) Efflux and atherosclerosis: the clinical and biochemical impact of variations in the ABCA1 gene. Arterioscler Thromb Vasc Biol 23:1322-1332

95. Sone H, Shimano H, Shu M, Nakakuki M, Takahashi A, Sakai M, Sakamoto Y, Yokoo T, Matsuzaka K, Okazaki H, Nakagawa Y, Iida KT, Suzuki H, Toyoshima H, Horiuchi S, Yamada N (2004) Statins downregulate ATP-binding-cassette transporter A1 gene expression in macrophages. Biochem Biophys Res Commun 316:790-794

96. Sporstol M, Tapia G, Malerod L, Mousavi SA, Berg T (2005) Pregnane $\mathrm{X}$ receptor-agonists down-regulate hepatic ATP-binding cassette transporter A1 and scavenger receptor class B type I. Biochem Biophys Res Commun 331:1533-1541

97. Srivastava RA (2002) Estrogen-induced regulation of the ATPbinding cassette transporter A1 (ABCA1) in mice: a possible mechanism of atheroprotection by estrogen. Mol Cell Biochem 240:67-73

98. Stefkova J, Poledne R, Hubacek JA (2004) ATP-binding cassette $(\mathrm{ABC})$ transporters in human metabolism and diseases. Physiol Res 53:235-243 
99. Strobach D, Lorenz RL (2003) The bisphosphonate ibandronate stimulates reverse cholesterol transport out of monocytoid cells by enhanced ABCA1 transcription. Biochem Biophys Res Commun 307:23-30

100. Suzuki S, Nishimaki-Mogami T, Tamehiro N, Inoue K, Arakawa R, Abe-Dohmae S, Tanaka AR, Ueda K, Yokoyama S (2004) Verapamil increases the apolipoprotein-mediated release of cellular cholesterol by induction of ABCA1 expression via liver $\mathrm{X}$ receptor-independent mechanism. Arterioscler Thromb Vasc Biol 24:519-525

101. Szanto A, Benko S, Szatmari I, Balint BL, Furtos I, Ruhl R, Molnar S, Csiba L, Garuti R, Calandra S, Larsson H, Diczfalusy U, Nagy L (2004) Transcriptional regulation of human CYP27 integrates retinoid, peroxisome proliferator-activated receptor, and liver X receptor signaling in macrophages. Mol Cell Biol 24:8154-8166

102. Takahashi Y, Smith JD (1999) Cholesterol efflux to apolipoprotein $\mathrm{AI}$ involves endocytosis and resecretion in a calciumdependent pathway [see comments]. Proc Natl Acad Sci USA 96:11358-11363

103. Tall AR, Costet P, Luo Y (2000)‘Orphans' meet cholesterol. Nat Med 6:1104-1105

104. Tang C, Vaughan AM, Oram JF (2004) Janus kinase 2 modulates the apolipoprotein interactions with $\mathrm{ABCA} 1$ required for removing cellular cholesterol. J Biol Chem 279:7622-7628

105. Theodoulou FL, Holdsworth M, Baker A (2006) Peroxisomal ABC transporters. FEBS Lett 580:1139-1155

106. Trompier D, Chimini G (2005) ABCA1. Molecule page. Nature Alliance For Cellular Signalling DOI 10.1038/mp.a002593.01

107. Uitto J (2005) The gene family of $A B C$ transporters-novel mutations, new phenotypes. Trends Mol Med 11:341-343

108. Valledor AF (2005) The innate immune response under the control of the LXR pathway. Immunobiology 210:127-132

109. Van Eck M, Pennings M, Hoekstra M, Out R, Van Berkel TJ (2005) Scavenger receptor BI and ATP-binding cassette transporter A1 in reverse cholesterol transport and atherosclerosis. Curr Opin Lipidol 16:307-315

110. van Meer G, Halter D, Sprong H, Somerharju P, Egmond MR (2006) ABC lipid transporters: extruders, flippases, or flopless activators? FEBS Lett 580:1171-1177

111. Venkateswaran A, Laffitte BA, Joseph SB, Mak PA, Wilpitz DC, Edwards PA, Tontonoz P (2000) Control of cellular cholesterol efflux by the nuclear oxysterol receptor LXR alpha. Proc Natl Acad Sci USA 97:12097-12102

112. Wagsater D, Dimberg J, Sirsjo A (2003) Induction of ATPbinding cassette A1 by all-trans retinoic acid: possible role of liver X receptor-alpha. Int J Mol Med 11:419-423

113. Wahrle SE, Jiang H, Parsadanian M, Hartman RE, Bales KR, Paul SM, Holtzman DM (2005) Deletion of Abcal increases Abeta deposition in the PDAPP transgenic mouse model of Alzheimer disease. J Biol Chem 280:43236-43242

114. Wang N, Lan D, Chen W, Matsuura F, Tall AR (2004) ATPbinding cassette transporters G1 and G4 mediate cellular cholesterol efflux to high-density lipoproteins. Proc Natl Acad Sci USA 101:9774-9779

115. Wang XQ, Panousis CG, Alfaro ML, Evans GF, Zuckerman SH (2002) Interferon-gamma-mediated downregulation of cholesterol efflux and $\mathrm{ABC} 1$ expression is by the Stat 1 pathway. Arterioscler Thromb Vasc Biol 22:e5-e9

116. Wang Y, Oram JF (2002) Unsaturated fatty acids inhibit cholesterol efflux from macrophages by increasing degradation of ATP-binding cassette transporter A1. J Biol Chem 277:5692-5697

117. Wellington CL, Walker EK, Suarez A, Kwok A, Bissada N, Singaraja R, Yang YZ, Zhang LH, James E, Wilson JE, Francone O, McManus BM, Hayden MR (2002) ABCA1 mRNA and protein distribution patterns predict multiple different roles and levels of regulation. Lab Invest 82:273-283

118. Wong J, Quinn CM, Brown AJ (2004) Statins inhibit synthesis of an oxysterol ligand for the liver $\mathrm{x}$ receptor in human macrophages with consequences for cholesterol flux. Arterioscler Thromb Vasc Biol 24:2365-2371

119. Yu L, von Bergmann K, Lutjohann D, Hobbs HH, Cohen JC (2004) Selective sterol accumulation in ABCG5/ABCG8-deficient mice. J Lipid Res 45:301-307

120. Zanotti I, Favari E, Sposito AC, Rothblat GH, Bernini F (2004) Pitavastatin increases ABCA1-mediated lipid efflux from Fu5AH rat hepatoma cells. Biochem Biophys Res Commun 321:670-674

121. Zeng L, Liao H, Liu Y, Lee TS, Zhu M, Wang X, Stemerman MB, Zhu Y, Shyy JY (2004) Sterol-responsive element-binding protein (SREBP) 2 down-regulates ATP-binding cassette transporter A1 in vascular endothelial cells: a novel role of SREBP in regulating cholesterol metabolism. J Biol Chem 279:48801-48807 